\title{
Estimation of soil erosionability in the stream basin of Pillahuinco Grande, Province of Buenos Aires, Argentina
}

\author{
Fernanda J. Gaspari¹, Alfonso M. Rodríguez Vagaría, \\ and Gabriela E. Senisterra \\ Facultad de Ciencias Agrarias y Forestales, Universidad Nacional de La Plata. Diagonal 113 No 469. CP \\ 1900. La Plata. Provincia de Buenos Aires, Argentina.
}

\begin{abstract}
F.J. Gaspari, A.M. Rodríguez Vagaría, and G.E. Senisterra. 2009. Estimation of soil erosionability in the stream basin of Pillahuinco Grande, Buenos Aires province, Argentina. Cien. Inv. Agr. 36(1): 43-52. In a hydrographic watershed, the erosionability ( $\mathrm{K}$ factor) of the soil evaluation depends on the technical resources, developed applied sciences, and spatial technology available. For the determination of erosionability in the watershed of Pillahuinco Grande`s Creek (Argentina) $\left(38^{\circ} \mathrm{S}, 61^{\circ} 15^{\prime} \mathrm{W}\right)$, the Universal Soil Loss Equation (USLE) was used by applying a geographic information system (GIS) for the cartographic evaluation. A database of geological, environmental, and soil associations was developed, which indicated that geomorphologic variability, caused by geology and soil, significantly determines the spatial variation of the $\mathrm{K}$ factor values, in a range from 0.02 to $0.69\left(\left(\mathrm{t} \cdot \mathrm{m}^{2} \cdot \mathrm{h}\right) \cdot(\mathrm{ha} \cdot \mathrm{J} \cdot \mathrm{cm})^{-1}\right)$. A new quantification was determined with the simplified $\mathrm{K}$ factor from the USLE model and with the two generated equations, K1, starting from sand, silt and organic matter, and K2, beginning from sand and organic matter. A linear regression and the coefficient of efficiency $\left(\mathrm{R}_{\mathrm{N}}{ }^{2}\right)$ were established, which indicated the adjustment of the $\mathrm{K}$ factor for each developed pattern. The $\mathrm{R}_{\mathrm{N}}{ }^{2}$ correlation value was 0.76 in relation to the simplified $\mathrm{K}$ factor, 0.87 to $\mathrm{K} 1$, and 0.86 to $\mathrm{K} 2$ (very similar due to the small significance of silt in the equation). This relationship demonstrates that the application of $\mathrm{K} 1$ and $\mathrm{K} 2$, according to the readiness of the data, is more specific and exact than the results obtained by applying the simplified $\mathrm{K}$ factor.
\end{abstract}

Key words: GIS, soil, soil erosion, USLE, watershed.

\section{Introduction}

The hydrographic basin is the unit of study and administration in agrohydrological management, and it is defined as a territorial space formed by a main water stream, its tributaries, and a water collector area, which are separated by the water dividing line.

Received 05 March 2007. Accepted 25 September 2007. ${ }^{1}$ Corresponding author: fgaspari@agro.unlp.edu.ar
The presence of man in a basin creates a series of problems that arise from an irrational use of natural resources. Among these are the degradation and loss of soil productivity, erosion, floods, desertification, water eutrophication, forest destruction and loss of biodiversity. Because of these problems, the human population experiences a decrease in quality of life, which, in extreme cases, ends with migrations towards large cities (Gaspari, 2000).

The planning and management of sustainable basin development are necessary for under- 
standing and stabilizing the use and management of natural resources and as a way to establish a methodology for planning the territorial arrangement of the Buenos Aires mountainous basins (Gaspari, 2000).

The hydrological restoration of forest, the active response of man to the destruction or deterioration of soil resources, vegetation and water, is the due to actions that must be addressed globally, which sometimes entail high, continuous investments for long periods. Their effects are beneficial only through time (Del Palacio, 1999).

In the mountainous basins of the Coronel Pringles Partido, Province of Buenos Aires, economical growth is historically related to agricultural and livestock production. The agricultural production corresponds to $50 \%$ of the district's production. The main crops are wheat, soybean, barley, sunflower, sorghum and maize, and $70 \%$ of the production is exported. Coronel Pringles is currently part of Consorcio Intermunicipal de Desarrollo Regional (CIDERE) that recently opened the Regional Development Agency (Agencia de Desarrollo Regional, ADR). It is intended to foster strategic sectorial alliances, coordinate public and private efforts for fostering regional development, and promote cooperation, employment generation, and economical, social, and environmental sustainability. The area of study comprises the Pillahuinco Grande stream basin located in the Mountainous System of Ventania Partido of Coronel Pringles, in the southwest of the Buenos Aires Province, Argentina. It covers a surface of 109,353,95 ha (Figure 1). Serious environmental problems are observed in this zone, due to the degradation and loss of the soil surface by water erosion (Gaspari and Rodríguez Vagaría, 2006).

The surface water erosion results in the loss of the productive soil potential. Therefore, it is important to study the processes generating these problems. There are several factors affecting soil stability, which can be grouped as climatic, edafic, terrain or vegetation factors (Vich, 1989; Kirkby and Morgan, 1994).

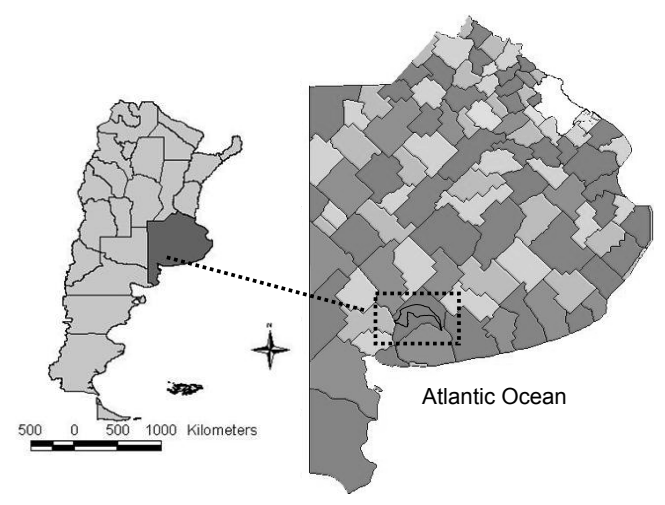

Figure 1. Geographical localization of the Pillahuinco Grande Watershed Basin ( $\left.38^{\circ} \mathrm{S} ; 61^{\circ} 15^{\prime} \mathrm{W}\right)$. Buenos Aires Province, Argentina.

Numerous methods have been developed for determining soil losses. In 1965, Wischmeier and Smith presented a model called the USLE (Universal Soil Loss Equation), in which the factors determining the amount of aroused sediments include a fifth factor of erosion control by crop practices. It is expressed as $\mathrm{A}=\mathrm{R} \times \mathrm{K} \times \mathrm{LS} \times \mathrm{C}$ $\mathrm{x} P$, where $\mathrm{A}$ is the soil losses $\left(\mathrm{t} \cdot \mathrm{ha}^{-1} \mathrm{year}^{-1}\right), \mathrm{R}$ is the index of pluvial erosion $\left((\mathrm{J} \cdot \mathrm{cm}) \cdot\left(\mathrm{m}^{2} \cdot \mathrm{h}\right)^{-1}\right), \mathrm{K}$ is the soil erosionability factor $\left(\left(\mathrm{t} \cdot \mathrm{m}^{2} \cdot \mathrm{h}\right) \cdot(\mathrm{ha} \cdot \mathrm{J} \cdot \mathrm{cm})^{-1}\right)$, LS is the pending factor, $\mathrm{C}$ is the crop factor, and $\mathrm{P}$ is the dimensionless crop practices factor (Mintegui Aguirre and López Unzu, 1990; Kirkby and Morgan, 1994; López Cadenas de Llano, 1998; Mintegui Aguirre et al., 2006).

Regardless of other factors of erosion, the susceptibility of soils to water erosion is determined from the content, texture, and structure of organic matter (OM), which are unlikely to be available for a whole hydrographic basin (Irurtia et al., 1984).

The objective of this work was to estimate the coefficient of soil erosionability $(\mathrm{K})$ adjusted to the Pillahuinco Grande stream basin according to geospatial distribution. The zoning and adjustment of $\mathrm{K}$ will generate a dynamic digital tool for determining the soil losses by surface water erosion in the Pillahuinco Grande stream basin. 


\section{Materials and methods}

The stream basin of Pillahuinco Grande $\left(38^{\circ} \mathrm{S}\right.$, $61^{\circ} 15^{\prime} \mathrm{W}$ ) is characterized by a highly variable, temperate, and sub-humid climate with moderate temperatures.

Harrington (1947) described how the southern mountains of the Province of Buenos Aires form a cluster of elevations contrasting with the general level of the Pampas. The terrain presents different levels of erosion with drain lines of dendritic design, attached mainly to modern eolic sediments. The surrounding plain, free of rocky formations, presents a zone more immediate to the sierra (perimountainous) with uneven surfaces more or less noticeable, which are more evident near streams.

The geological formations present in the region were classified by Tricart (1973) as Platense eolic, Platense aqueous, Lujanian eolic and Lujanian aqueous, which explain the soil genesis of the area under study. Although all contribute to the soil formation in the region, the extensive mantle surface composed of the eolic postPampa sediments is the most important and predominant material forming the soils.

The region under study offers a wide range of edaphic and environmental situations due to the diverse action from the factors mentioned above. From the topographical point of view, there are strong terrain variations that rule the arrangement and extension of consolidated rocky formations, overlaying sedimentary deposits, drain conditions, runoff surface and accumulation of rainwater participating in edaphic processes. The climate, terrain, structure and composition of the original geological material and the vegetation are factors that, in their regional variations, determine the edaphogenesis of the region's soils. The region is divided into four geological environments:

Mountainous environment. The extensive Lujanian eolic mantle along with the remaining Pampean tufa mantle and the Lujanian aqueous surfaces spreads over hillsides and summits and reduces the exposition of old consolidated rocks. Therefore, the rocky formations are scarce. The created terrain generally reflects the underlying rock, and the external form was adapted by an intense erosive action based on diverse geological structures. In the mountainous environment, the post-Pampean loess may be supported directly on old rocks.

Intramountainous environment. The intramountainous environment comprises the central and interior region of the sierra environment and includes the cluster of depressions and longitudinal and transversal valleys. The materials filling these depressions are predominantly thick and of the colluvial type that are in contact with mountains, of loessic character on the general plain, and are fluvial-lacustrian and partly covered by retransported edafic material towards the streams' axes. Because of its brittle nature, it is easily eroded by water action, which leads to the formation of large gullies. The streams cut the loessic mantle, and only the narrow fluvial bed maintains alluvial characteristics.

Perimountainous environment. This environment develops in attachment to the sierra and surrounds it and its slopes. When the transgressive accumulation of the Lujanian eolic deposits occurs, an inclined plane is defined, leaning against the mountains, and a slope decreases slowly to fuse with the plain. The dense loess accumulation in the foothill slowly decreases and is thus present only at isolated spots. The most common places are the hills, which originated by the dissection of the general plain produced by streams running down the mountains.

Plain environment. This environment extends externally to the perimountainous environment and is characterized by the loss of loessic cover homogeneity as the presence of tufa becomes more abundant. However, some aspects of the plain are very different, so different sectors are noteworthy: a. Northern Sector: In the extended plain sector, it presents homogeneous characteristics. The fluvial streams extend in scarcely carved wider valleys subject to flooding. The unevenness between the stream beds and the plain reaches a barely noticeable inflexion. b. Spills Sector: The mountainous streams spread superficially on the plain to generate "spills." The detritic material is characterized by abundant dissolved calcium carbonate, which forms 
Table 1. Soil associations according to Spinelli Zinni (1978) (Figure 2).

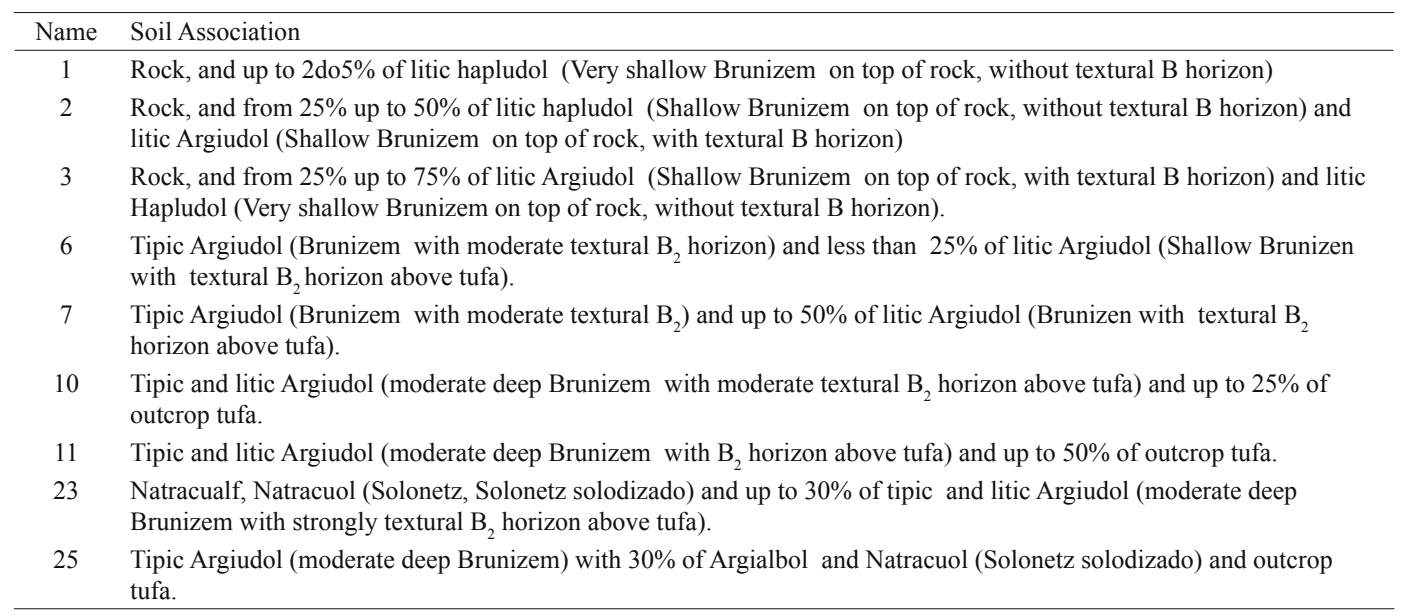

a calcareous layer through evaporation. During the last dry period, the floods concentrate the major proportion of soluble salts (sodium), causing salination and/or alkalization of the affected areas. c. Southeast Sector: The Lujanian eolic accumulation is dense and abundant at the foot of the mountains and becomes thinner farther away from the mountains. The accumulation respects the pre-existing terrain and maintains the topographical relationships.

Soil identification (Table 1), geological associations, distributions and local variations allow for the classification of the environment. As the soil is an integral and functional part of the environment where it is present, it is important to show how geomorphologic variations influence soil constitution and how the edaphological classification adjusts to the surrounding geological environments (Table 2).

The Geographic Information System (Sistema de Información Geográfica, SIG) allowed for the elaboration of the edaphic base cartography and geological associations of the basin of the Arroyo Pillahuinco Grande (Idrisi Kilimanjaro 14.0, Clark University, USA, 2003). The procedure consisted of generating and zoning the basin according to the maps of soil association and geological environments, by means of digitalizing the analogical format (scale 1:250.000).

In order to determine the soil erosionability $(\mathrm{K})$, the only published data (Spinelli Zinni et al.,
1978) were used to elaborate, arrange, analyze, classify and interpret a geospatial database.

The development and application of a cartographic model allowed for data analysis and recording with the SIG Idrisi Kilimanjaro, which permitted space tracking (López Cadenas de Llano, 1998; Gaspari et al., 2006).

The texture, OM, permeability and structure data were extracted from the most representative area profiles according to Spinelli Zinni (1978). In order to determine the factor K, it was necessary to identify the representative profile of the series type (Scotta et al., 1986). It is worth mentioning that these profiles were extrapolated according to the relationship of soil association and location in respect to the geological environments.

The soil erosionability $(\mathrm{K})\left(\mathrm{t} \cdot \mathrm{m}^{2} \cdot \mathrm{h}\right) \cdot(\mathrm{ha} \cdot \mathrm{J} \cdot \mathrm{cm})^{-1}$ was calculated by Formula 1, according to the universal equation of soil loss (USLE) (Mintegui Aguirre and López Unzú, 1990):

$100 \mathrm{~K}=10^{-4} 2.71 \mathrm{M}^{1,14}(12-a)+4.20(b-2)+3.23(c-3)$

where $\mathrm{M}$ is the product of soil particles between 0.002 and $0.1 \mathrm{~mm}$ of diameter and is expressed in percentages by the percentage of soil particles between 0.002 and $2 \mathrm{~mm}$ in diameter; $a$ is the percentage of $\mathrm{OM}$ (for the calculations, 1.72 of organic carbon was used when the OM 
percentages were not available); $b$ represents the soil structure coded according to the granule size; $c$ describes the class of permeability soil, according to the USDA (Wischmeier and Smith, 1978).

For the estimation of simplified factor $\mathrm{K}(\mathrm{Ks})$, the values $b$ and $c$ may be dispensed, and $\mathrm{Eq} 2$ is obtained (Mintegui Aguirre and López Unzú, 1990):

$\mathrm{Ks}=10^{-6} 2.71 \mathrm{M}^{1,14}(12-\mathrm{a})$

[Eq 2]

Once the erosionability $\mathrm{K}$ factor and $\mathrm{Ks}$ for each profile were determined, an area weighted by the factor $(\propto)$ was made according to the area of influence to establish the coefficient for each soil association according to the geological environment.

These results allowed for the generation of a mathematical adjustment model adapted to the Pillahuinco Grande stream basin, producing two equations to modify and promote the $\mathrm{K}$ determination factor. Thus, laboratory data obtained by processing simple soil samples taken from field were used and corroborated with data records from studies by Spinelli Zinni (1978). From the development of a regression equation and the inclusion of the percentages of sand, silt and $\mathrm{OM}$, the $\mathrm{K} 1$ value was obtained. A second regression equation showing how the independent variables, sand and OM, allowed for obtaining the $\mathrm{K} 2$ value. These two models allowed for representing the soil erosionability in the ba$\sin$ in a simplified and practical form.

The goodness of fit between the data obtained with the original model (Eq 1) and the data obtained with the other three models (Ks, K1 and K2) was evaluated by a linear regression analysis with a coefficient of determination $\left(\mathrm{R}^{2}\right)$ by the minimun square method (Navidi, 2006) and the criterion of efficiency by Nash-Sutcliffe (1970). The Nash-Sutcliffe regression $\left(\mathrm{R}_{\mathrm{N}}^{2}\right)$ represents the relationship between the observed and predicted values (Llorens, 2003).

\section{Results and discussion}

The zoning of the geological environments and the soil associations are presented in Figure 2A and $\mathrm{B}$, respectively. The contributions of different soil associations with respect to the geological environments in the Pillahuinco Grande stream basin are shown in Table 2.

Table 2. Area and proportion of soil associations by geological environment of the Pillahuinco Grande Watershed.

\begin{tabular}{|c|c|c|c|c|c|c|c|c|c|c|c|c|c|}
\hline \multirow[b]{3}{*}{ Soils } & \multicolumn{12}{|c|}{ Geological Environment } & \multirow{3}{*}{$\begin{array}{c}\text { Area } \\
\text { ha }\end{array}$} \\
\hline & \multicolumn{2}{|c|}{ Highland } & \multicolumn{2}{|c|}{ Intrahigland } & \multicolumn{2}{|c|}{ Perihighland } & \multicolumn{2}{|c|}{$\begin{array}{l}\text { Septentrional } \\
\text { Plain }\end{array}$} & \multicolumn{2}{|c|}{$\begin{array}{l}\text { Spill } \\
\text { Plain }\end{array}$} & \multicolumn{2}{|c|}{$\begin{array}{l}\text { Sudoriental } \\
\text { Plain }\end{array}$} & \\
\hline & ha & $\%$ & ha & $\%$ & ha & $\%$ & ha & $\%$ & ha & $\%$ & ha & $\%$ & \\
\hline 1 & 1466.23 & 100.00 & & & & & & & & & & & 1466.23 \\
\hline 2 & 7214.54 & 92.88 & 548.33 & 7.06 & 4.68 & 0.06 & & & & & & & 7767.55 \\
\hline 3 & 8370.75 & 90.75 & 741.75 & 8.04 & 49.84 & 0.54 & 3.69 & 0.04 & 53.26 & 0.58 & 4.41 & 0.05 & 9224.42 \\
\hline 6 & 715.30 & 14.79 & 2269.06 & 46.91 & 1852.53 & 38.30 & & & & & & & 4836.89 \\
\hline 7 & 1169.35 & 7.69 & 6870.79 & 45.18 & 2985.71 & 19.63 & 2223.09 & 14.62 & 134.32 & 0.88 & 1824.37 & 12.00 & 15207.72 \\
\hline 10 & 636.67 & 3.57 & & & 75.48 & 0.42 & 2435.22 & 13.67 & 5894.59 & 33.08 & 8772.08 & 49.23 & 17817.92 \\
\hline 11 & & & & & & & 871.93 & 74.78 & 294.09 & 25.22 & & & 1166.02 \\
\hline 23 & & & 56.14 & 0.12 & 294.18 & 0.60 & 1590.83 & 3.26 & 45957.01 & 94.23 & 872.11 & 1.79 & 48771.30 \\
\hline 25 & & & & & & & & & 3095.92 & 100.00 & & & 3095.92 \\
\hline $\begin{array}{l}\text { Area, } \\
\text { ha }\end{array}$ & 19572.84 & & 10486.07 & & 5262.42 & & 7124.76 & & 55429.18 & & 11472.97 & & 109353.95 \\
\hline
\end{tabular}




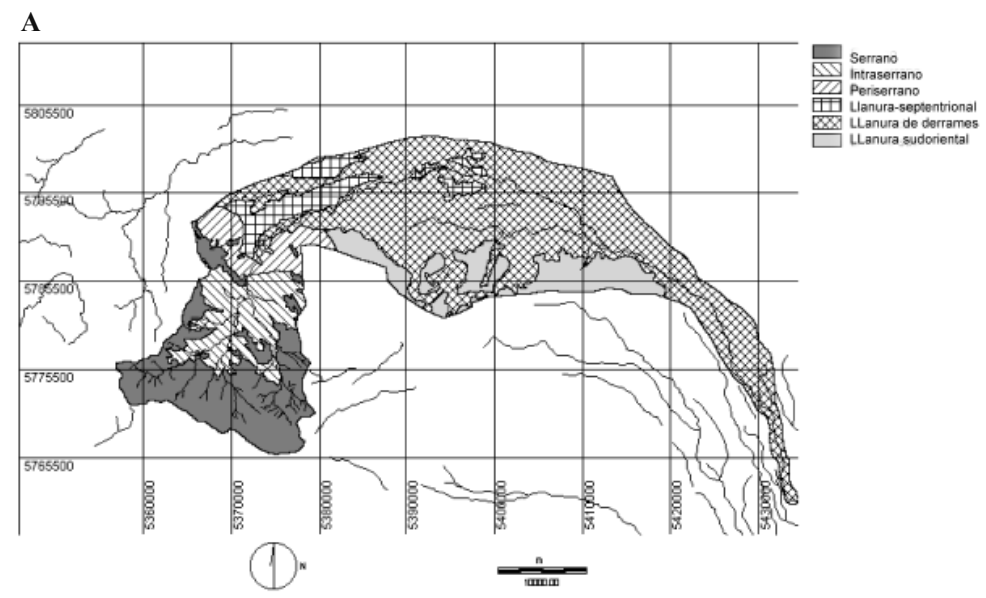

B

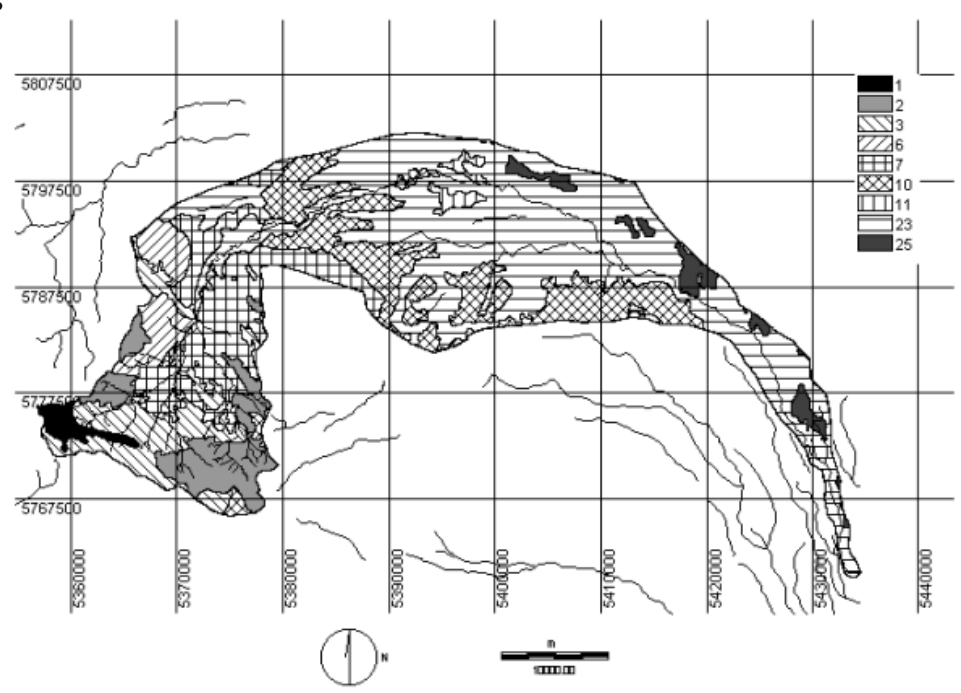

Figure 2. A. Geologic environment map of the Pillahuinco Grande Watershed. B. Soil association map of the Pillahuinco Grande Watershed. Buenos Aires Province, Argentina (for legent, see Table 1).

The database, derived from the study by Spinelli Zinni (1978) and including the soil profile according to the geological environment, is presented in Table 3. The factor $\propto$, representing the occupation degree, was used to weight the $\mathrm{K}$ value in homogeneous surfaces for each soil association by implementing the methodology in Eqs 1 and 2. The weighted $\mathrm{K}$ values and simplified $\mathrm{K}$ values varied according to the intrinsic characteristics of each homogeneous zone determined by SIG, where the content of OM was the most influential variable in the minimum extreme of $\mathrm{K}$ and $\mathrm{Ks}$ values, and the soil structure and permeability were most influential in the maximum extreme. This presented a range between 0.0144 and $0.6874\left(\mathrm{t} \cdot \mathrm{m}^{2} \cdot \mathrm{h}\right) \cdot(\mathrm{ha} \cdot \mathrm{J} \cdot \mathrm{cm})^{-1}$ for $\mathrm{K}$ and a narrower range, between 0.0467 and $0.5121\left(\mathrm{t} \cdot \mathrm{m}^{2} \cdot \mathrm{h}\right) \cdot(\mathrm{ha} \cdot \mathrm{J} \cdot \mathrm{cm})^{-1}$, for Ks.

The mathematical $\mathrm{K}$ model adjusted to the zone under study established two new equations. The first (Eq 3) was determined through a linear multiple regression, in which the percentages of sand, silt and OM were used as independent variables and the factor $\mathrm{K}$ calculated from the USLE model was a dependent variable:

$\mathrm{K} 1=1.63929-0.0161516 \times(\%$ sand $)-0.00686702 \times(\%$ silt $)$ $-0.0746648 \times(\% \mathrm{OM})$

[Eq 3] 
Table 3. Database for the determination of the erosionability factor for soil profile $\left(\mathrm{K}_{\mathrm{i}}\right)$ and pondered by soil association according to USLE model (K) and simplified USLE (Ks) ((t.m².h) (ha.J.cm)-1).

\begin{tabular}{|c|c|c|c|c|c|c|c|c|c|c|c|}
\hline \multirow[b]{2}{*}{ Soil } & \multicolumn{7}{|c|}{ Soil data base } & \multicolumn{2}{|c|}{ USLE } & \multicolumn{2}{|c|}{ Simplify USLE } \\
\hline & $\begin{array}{c}\% \\
\text { particles } \\
0.002-0,1 \\
\mathrm{~mm}\end{array}$ & $\begin{array}{c}\% \\
\text { particles } \\
0.002-2 \\
\mathrm{~mm}\end{array}$ & M & $\begin{array}{l}\mathrm{a} \\
\%\end{array}$ & $\mathrm{~b}$ & $\mathrm{c}$ & $\propto$ & $\mathrm{K}_{\mathrm{i}}$ & K & $\mathrm{K}_{\mathrm{is}}$ & Ks \\
\hline 1 & 42.0 & 74.0 & 3108.0 & 10.2 & 2 & 2 & 1 & 0.0144 & 0.0144 & 0.0467 & 0.0467 \\
\hline 2 & 57.9 & 74.0 & 4284.6 & 9.8 & 3 & 2 & 1 & 0.0920 & 0.0920 & 0.0823 & 0.0823 \\
\hline 3 & 51.5 & 70.5 & 3630.7 & 9.8 & 2 & 4 & 1 & 0.1005 & 0.1005 & 0.0682 & 0.0682 \\
\hline \multirow{3}{*}{6} & 71.1 & 78.7 & 5595.6 & 3.5 & 3 & 3 & 0.55 & 0.4734 & \multirow{2}{*}{0.4600} & 0.2373 & \multirow{2}{*}{0.2118} \\
\hline & 75.0 & 78.2 & 5865.0 & 4.5 & 3 & 3 & 0.45 & 0.4436 & & 0.1807 & \\
\hline & 72.9 & 79.0 & 5759.1 & 3.9 & 2 & 3 & 0.58 & 0.4248 & \multirow{4}{*}{0.3617} & 0.4248 & \multirow{4}{*}{0.3866} \\
\hline \multirow[t]{3}{*}{7} & 75.0 & 78.2 & 5865.0 & 4.5 & 3 & 3 & 0.26 & 0.4436 & & 0.4016 & \\
\hline & 38.8 & 83.6 & 3243.7 & 3.8 & 2 & 3 & 0.16 & 0.2235 & & 0.2235 & \\
\hline & 21.2 & 91.3 & 1935.6 & 1.1 & 2 & 2 & 0.14 & 0.1326 & & 0.1649 & \\
\hline \multirow[t]{2}{*}{10} & 68.3 & 73.5 & 5020.0 & 5.2 & 3 & 3 & 0.35 & 0.3469 & \multirow[t]{2}{*}{0.2513} & 0.3049 & \multirow[t]{2}{*}{0.2361} \\
\hline & 30.1 & 86.7 & 2609.7 & 2.2 & 3 & 2 & 0.51 & 0.2182 & & 0.2085 & \\
\hline 11 & 46.5 & 82.4 & 3831.6 & 1.2 & 3 & 1 & 1 & 0.3333 & 0.3334 & 0.3559 & 0.3559 \\
\hline \multirow{2}{*}{23} & 73.9 & 82.7 & 6111.5 & 2.4 & 3 & 3 & 0.04 & 0.5808 & \multirow{2}{*}{0.6874} & 0.5388 & \multirow{2}{*}{0.5121} \\
\hline & 72.0 & 74.9 & 5392.8 & 1.5 & 4 & 6 & 0.96 & 0.6919 & & 0.5110 & \\
\hline 25 & 68.3 & 73.5 & 5020.0 & 5.2 & 3 & 3 & 1 & 0.3469 & 0.3469 & 0.3049 & 0.3049 \\
\hline
\end{tabular}

According to the $\mathrm{R}^{2}$ value, $87.35 \%$ of the variability of factor $\mathrm{K} 1$ is explained by the three variables (sand, silt and OM), with a $99 \%$ confidence level. By individually analyzing each variable, the value of probability for silt is 0.49 , which is non-significant and with a confidence level of $90 \%$. The analysis of the independent variables of $\mathrm{K} 1$ determined that the model may be simplified to a new expression, given by Eq 4 (K2):

$\mathrm{K} 2=1.15281-0.0109355 \times(\%$ sand $)-0.0703187 \times(\% \mathrm{OM})$ [Eq 4]

The $\mathrm{R}^{2}$ value for $\mathrm{K} 2$ explains that $86.76 \%$ of the variation was due to the sand and $\mathrm{OM}$ values. In order to establish the relationships among the formulas, a simple linear regression was used $\left(\mathrm{R}^{2}\right)$, where the $\mathrm{K}$ was correlated with $\mathrm{Ks}, \mathrm{K} 1$ and $\mathrm{K} 2$ (Figure 3A, B and C). The dispersion of the data expressed with the graphics allowed for verifying the goodness of fit among the different $\mathrm{K}$ values. This was expressed with a major adjustment of $\mathrm{R}^{2}$ with the relationship between $\mathrm{K}$ and $\mathrm{K} 1$ (0.86), without significant differences with the $\mathrm{K}$ and $\mathrm{K} 2(0.85)$ relationship. In the case of $\mathrm{Ks}$, an $\mathrm{R}^{2}$ value of 0.76 was obtained. The application of $\mathrm{R}_{\mathrm{N}}^{2}$ expressed the results homologically, since a value of 0.87 with a $\mathrm{K} 2$ of 0.86 was obtained in the relationship of $\mathrm{K}$ with $\mathrm{K} 1$. However, the value with Ks was 0.67.

The regression analysis and the use of the criteria by Nash-Sutcliffe (1970) established that the proposed formulas adjust more precisely with the $\mathrm{K}$ value from the USLE than the simplified formula.

The obtained results allowed for defining a new methodology for the determination of soil erosionability in the stream basin of Pillahuinco Grande according to geospatial distribution. This erosionability was established simply with a high correlation to the values generated by $\mathrm{K}$ from the USLE and without the need of a wide database. Furthermore, the sand and OM data are inexpensive and easy to access and determine.

The present work includes new elements for the identification of the physical state of a hydrographic basin using a universal basic methodology and SIG. Although many investigators criticize the USLE due to a weak scientific base, it 

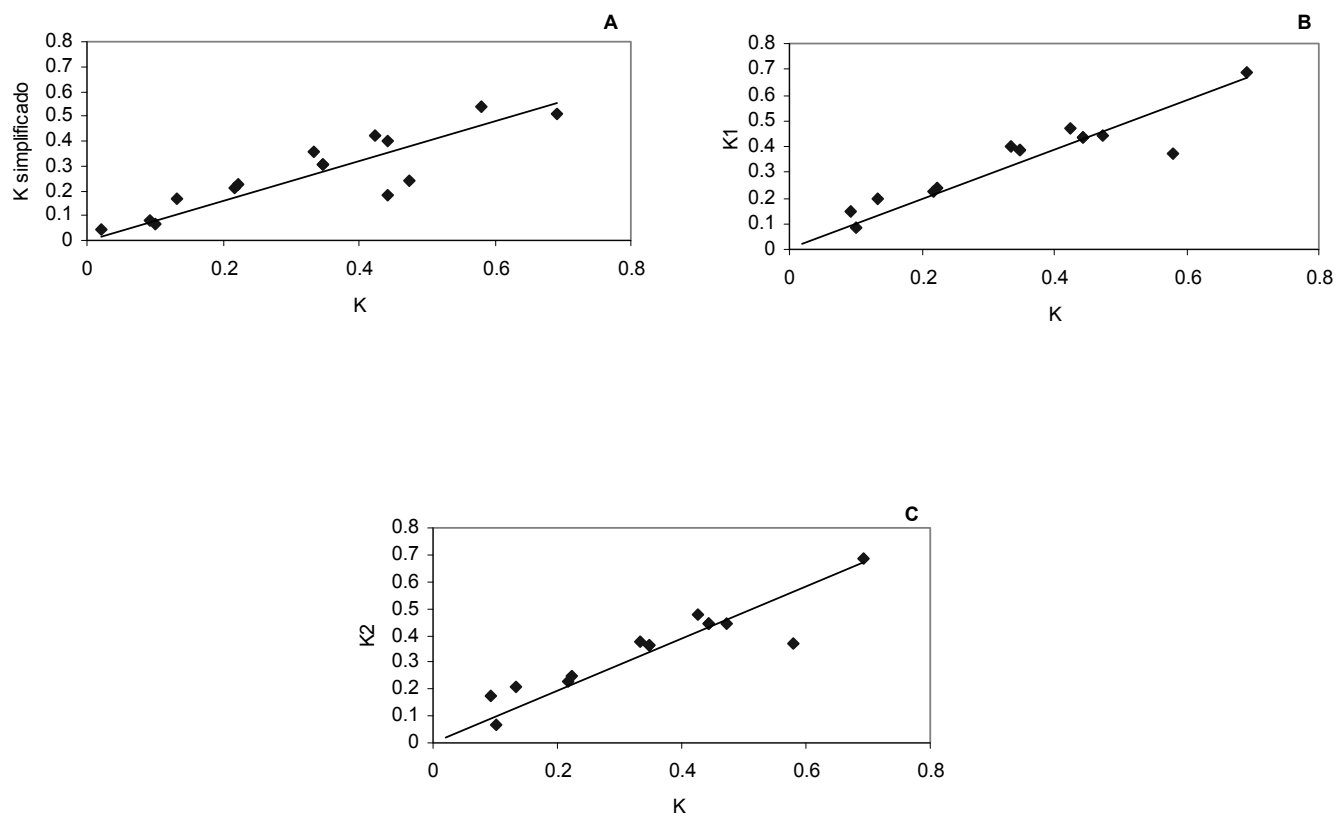

Figure 3. Lineal relationship between the erosionability factor K and simplified erosionability factor (Ks) (A) K1 (B) and $\left.\mathrm{K} 2(\mathrm{C})\left(\mathrm{t} \cdot \mathrm{m}^{2} \cdot \mathrm{h}\right)(\mathrm{ha} \cdot \mathrm{J} \cdot \mathrm{cm})^{-1}\right)$.

has been an effective tool to predict erosion and design strategies for soil conservation (Kirkby and Morgan, 1994).

The present work allowed for the estimation of the coefficient of erosionability and its space distribution for the Pillahuinco Grande stream basin, Argentina, through four parametric models, based on the factor K from the USLE, which is of great importance for evaluating the risks of surface water erosion. The geomorphologic variability, caused by geology and soils, significantly affected the spatial variation of the factor
$\mathrm{K}$. The zoning and adjustment of $\mathrm{K}$ generated a dynamic digital tool for using the USLE to determine erosionability for the estimation of soil loss by surface water erosion.

\section{Acknowledgements}

This work was carried out with financing from Proyectos de Investigación Científica y Tecnológica Orientados, PICTO 2003 Nº713.741, Secretaria de Ciencia y Técnica (SECyT), Argentina.

\section{Resumen}

F.J. Gaspari, A.M. Rodríguez Vagaría y G.E. Senisterra. 2009. Estimación de la erosionabilidad del suelo en la cuenca del arroyo Pillahuinco Grande, Provincia de Buenos Aires, Argentina. Cien. Inv. Agr. 36(1): 43-52. La evaluación de la erosionabilidad de los suelos $(\mathrm{K})$ en una cuenca hidrográfica, depende de la disponibilidad de los recursos técnicos, ciencias aplicadas desarrolladas y de tecnología espacial. La metodología utilizada para su determinación en la Cuenca del Arroyo Pillahuinco Grande (Argentina), fue la Ecuación Universal de Pérdida de Suelo (USLE), establecida a partir de la evaluación cartográfica con aplicación de sistema de información geográfica. Se desarrolló una base de datos de ambientes 
geológicos y asociaciones de suelos donde se observó que la variabilidad geomorfológica, causada por la geología y suelos, determina de manera significativa una variación espacial de los valores del factor $\mathrm{K}$, encontrándose en un rango de 0,02 a $0,69\left(\mathrm{t} \cdot \mathrm{m}^{2} \cdot \mathrm{h}\right) \cdot(\mathrm{ha} \cdot \mathrm{J} \cdot \mathrm{cm})^{-1}$. A partir de $\mathrm{K}$ se estableció una nueva cuantificación con el $\mathrm{K}$ simplificado de la USLE y con dos ecuaciones generadas $\mathrm{K} 1$ a partir de arena, limo y materia orgánica, y K2 con arena y materia orgánica. Se estableció una regresión lineal y el coeficiente de eficiencia $\left(\mathrm{R}_{\mathrm{N}}{ }^{2}\right)$ que indicó el ajuste de $\mathrm{K}$ para cada modelo desarrollado. Este último, expresó una correlación de 0,76 en relación con K simplificado, de 0,87 con K1 y de 0,86 con K2, muy semejantes debido a la baja significancia del limo sobre la ecuación. Esta relación demuestra que la aplicación de la K1 y $\mathrm{K} 2$, según disponibilidad de datos, es mas precisa y exacta que los resultados que pude aportar la fórmula del Ks.

Palabras clave: Cuenca, erosionabilidad de suelos, SIG, suelos, USLE.

\section{References}

Del Palacio, E. 1999. La restauración hidrológica forestal en España. Gestión sostenible de los recursos suelo, agua y vegetación. Ministerio de Medio Ambiente. Madrid, España. 75 pp.

Gaspari, F.J. 2000. Ordenamiento Territorial en Cuencas Serranas Aplicación de Sistemas de Información Geográfica (SIG). Ediciones Cooperativas. Buenos Aires, Argentina. 116 pp.

Gaspari, F.J., and A. Rodríguez Vagaría. 2006. Zonificación Ambiental de la Cuenca Pillahuinco Grande. Pages 9-10. In: XI Reunión Argentina de Agrometeorología. Facultad de Ciencias Agrarias y Forestales. Universidad Nacional de La Plata. Argentina.

Gaspari, F.J, M.G., Leonart, C. De La Peña, and A. Rodríguez Vagaría. 2006. Cartografía temática para la evaluación de la erosión hídrica superficial de la Cuenca del Arroyo Pillahuinco Grande. Provincia de Buenos Aires. Argentina. Pages 220-233. In: Tercer Congreso de la Ciencia Cartográfica. X Semana Nacional de la Cartografía. Centro Argentino de Cartografía. Buenos Aires. Argentina.

Harrington, H. 1947. Explicación de las cartas geológicas 33 m (Sierra de Cura Malal) y 34 m (Sierra de la Ventana), Provincia de Buenos Aires. Dirección de Minería y Geología. Volumen 61. Buenos Aires, Argentina.

Irurtia, C., J. Musto, and P. Culot. 1984. Evaluación de Riesgo de Erosión Hídrica en el Sector Argentino de la Cuenca del Plata. Publicación No 174, Instituto Nacional de Tecnología Agropecuaria (INTA). Castelar, Buenos Aires, Argentina. 32 pp.
Kirkby, M.J., and R.P.C. Morgan. 1994. Erosión de Suelos. Editorial Limusa. Noriega Editores. México, DF. México. 375 pp.

López Cadenas de Llano, F. 1998. Restauración Hidrológica Forestal de Cuencas y Control de la Erosión. Editorial TRAGSA. Madrid. España. 945 pp.

Llorens, P. 2003. La evaluación y modelización del balance hidrológico a escala de cuenca. Ecosistemas 2003/1. www.aeet.org (Accessed: January 2007).

Mintegui Aguirre, J. A., and F. López Unzú. 1990. La Ordenación Agrohidrológica en la Planificación. Servicio Central de Publicaciones del Gobierno Vasco. Madrid. España. 308 pp.

Mintegui Aguirre, J.A., J.C. Robredo Sánchez, J.I. García Viñas, and C. López Leiva. 2006. Introducción a la restauración hidrológicos-forestal de cuencas hidrográficas. Rev. Ecología 20:389414.

Nash, J.E., and J.V. Sutcliffe. 1970. River flow forecasting through conceptual models. A discussion of principles. Journal of Hydrology 10:282-290.

Navidi, W. 2006. Estadística para ingenieros y científicos. McGraw Hill Interamericana. México DF. México. 868 pp.

Scotta, E.S., L.A. Nani, A.A. Conde, A. Rojas, H. Castañeira, and O. Paparotti. 1986. Manual de Sistematización de Tierras para Control de Erosión Hídrica y Aguas Superficiales Excedentes. INTA, Serie No 17. Castelar. Argentina. $51 \mathrm{pp}$.

Spinelli Zinni, F. 1978. Estudio de situación Partido de Coronel Pringles, Provincia de Buenos Aires. INTA. Tomo III. Buenos Aires. Argentina. 92 pp. 
Tricart, J.L. 1973. Geomorfología de la Pampa Deprimida. Instituto Nacional de Tecnología Agropecuaria (INTA). Colección Científica XII. Buenos Aires, Argentina. 202 pp.

Vich, A.I.J. 1989. Erosión hídrica: Estimación y medición de pérdidas de suelo. Pages 118-130. In: Curso Latinoamericano sobre detección y control de la desertización. Editorial F.A. Roig. CRICYTME. Buenos Aires. Argentina.

Wischmeier, W.H., and D.D. Smith. 1978. Predicting rainfall erosion losses. A guide to conservation planning. U.S. Department of Agriculture. Agriculture Handbook No 537.58 pp. 